\title{
Rancang Model Expert System Pada Diagnosa Penyakit Diabetes Melitus Dengan Metode Forward Chaining
}

\author{
Diah Arifah $\mathrm{P}^{1}$, Laila Isyriyah ${ }^{2}$ \\ 1,2 Program Studi Teknik Informatika, STIKI Malang, Indonesia
}

\section{Info Artikel}

Riwayat Artikel

Diterima: 14-06-2021

Direvisi: $16-06-2021$

Disetujui: 23-06-2021

\section{Kata Kunci}

Forward chaining;

Expert System;

Diabetes mellitus;

Rancang Model;

Corresponding Author

Diah Arifah P.,

Program Studi Teknik

Informatika, STIKI Malang,

Tel. +62 81330722409

diah@stiki.ac.id

\begin{abstract}
ABSTRAK
Diabetes mellitus adalah penyakit yang ditimbulkan karena kekurangan produksi insulin (hormon yang diproduksi oleh pankreas) dan yang mengatur tingkat glukosa di dalam tubuh manusia. Bagi kebanyakan orang yang mengalami obesitas (kegemukan), penyakit diabetes melitus ini menjadi salah satu penyakit yang mengkhawatirkan. Penderita penyakit ini tidak semua orang yang mengalami obesitas dapat terserang. Pada penderita penyakit ini biasanya memiliki banyak gejala. Selain itu proses lama diagnosa serta biaya diagnosa penyakit yang cukup mahal membuat banyak penderita mengeluhkannya. Hal ini yang membuat masyarakat (pasien) membutuhkan konsultasi untuk menentukan hasil diagnosis dari gejala yang dialaminya. Pemodelan dalam penelitian ini menggunakan sistem pakar yang dapat memberikan solusi kepada masyarakat tanpa harus bertanya langsung kepada pakarnya. Penelitian ini bertujuan untuk merancang model expert system dengan menerapkan metode Forward Chaining dalam menentukan apakah seseorang tersebut menderita penyakit diabetes mellitus ataukah tidak. Sistem pakar ini menyediakan fasilitas konsultasi yang digunakan untuk melakukan tanya jawab antara sistem dengan pengguna (user) serta juga menyediakan fasilitas untuk melakukan edit knowledge.
\end{abstract}

\section{PENDAHULUAN}

\section{Latar Belakang}

Sistem pakar merupakan suatu sistem informasi yang menangkap dan menggunakan pengetahuan serta metode pengambilan keputusan yang digunakan oleh seorang atau beberapa orang ahli dalam bidang keahlian tertentu. Sistem pakar berlaku seperti seorang pakar pada bidangnya berisi fakta-fakta dan karakteristik untuk memecahkan masalah tertentu. Sistem pakar didasarkan pada sistem pengetahuan, sehingga memungkinkan komputer dapat mengambil kesimpulan yang tepat [1]. Pengetahuan yang ada disimpan dalam komputer. Dan pengguna dapat berkonsultasi pada komputer itu untuk suatu nasehat, lalu komputer dapat mengambil inferensi (menyimpulkan) seperti layaknya seorang pakar, kemudian menjelaskannya kepada pengguna tersebut, bila perlu dengan alasan-alasannya. Sistem pakar terkadang lebih baik kerjanya daripada seorang pakar manusia [2].

Sistem Pakar adalah bagian dari perangkat lunak khusus tingkat tinggi atau pemrograman tingkat tinggi bahasa, yang mencoba menduplikasi fungsi seorang ahli dalam bidang keahlian [3]. Sistem pakar atau expert system juga sudah banyak dikembangkan oleh sejumlah peneliti untuk berbagai bidang, namun yang banyak diimplementasikan adalah kesehatan [4].

Berdasarkan penelitian yang dilakukan oleh Siti Rofiqoh, Dedy Kurniadi dan Andi Riansyah (2020) yang berjudul Sistem Pakar Menggunakan Metode Forward Chaining untuk 
Diagnosa Penyakit Tanaman Karet menjelaskan bahwa system pakar menggunakan metode Forward Chaining dapat membantu para petani untuk berkonsultasi mengenai penyakit yang mungkin dialami oleh tanaman karetnya berdasarkan pada gejala yang ada [5].

Diabetes mellitus adalah penyakit yang ditimbulkan karena kekurangan produksi insulin (hormon yang diproduksi oleh pankreas) dan yang mengatur tingkat glukosa di dalam tubuh manusia. Bagi kebanyakan orang yang mengalami obesitas (kegemukan), penyakit diabetes melitus ini menjadi salah satu penyakit yang mengkhawatirkan, meskipun tidak semua orang yang mengalami obesitas (kegemukan) dapat terserang penyakit ini. beberapa ahli menyimpulkan bahwa penyakit diabetes mellitus adalah penyakit yang disebabkan karena tubuh kurang memproduksi insulin yang bekerja untuk menjaga keseimbangan glukosa dalam darah.Banyaknya gejala dalam penyakit diabetes mellitus, serta lamanya proses diagnosis dan biaya yang cukup mahal untuk melakukan proses diagnosis dalam menentukan apakah pasien menderita penyakit diabetes mellitus ataukah tidak. Dan juga dengan kemudahan adanya dokter ahli, terkadang terdapat pula kelemahan seperti jam kerja atau jam praktek dokter yang terbatas dan banyaknya pasien sehingga harus menunggu antrian. [6]

Hal ini yang membuat masyarakat (pasien) membutuhkan konsultasi untuk menentukan hasil diagnosis dari gejala yang dialaminya. Karena hal itulah maka dibutuhkan suatu alat bantu yang dapat mendiagnosa penyakit. Pemodelan dalam penelitian ini menggunakan sistem pakar yang dapat memberikan solusi kepada masyarakat tanpa harus bertanya langsung kepada pakarnya. Dalam penelitian yang telah dilakukan Rizka Nurliana Putri dan Leonard Goeirmanto (2020) yang berjudul Aplikasi Sistem Pakar untuk Diagnosa Penyakit Diabetes Mellitus dengan Algoritma Certainty Factor Berbasis Web menjelaskan bahwa aplikasi sistem pakar menggunakan metode certainty factor berhasil melakukan diagnosa dengan baik. Hal ini juga sesuai dengan nilai bobot yang sudah diberikan oleh pakar atau dokter dan juga sangat bermanfaat bagi masyarakat sebagai media edukasi tentang penyakit diabetes. [7]

Penelitian ini bertujuan untuk merancang model expert system dengan menerapkan metode forward chaining dalam menentukan apakah seseorang tersebut menderita penyakit diabetes mellitus ataukah tidak serta mengimplementasikan metode forward chaining dalam mendiagnosa penyakit diabetes mellitus sesuai dengan gejala yang ada. Sistem pakar ini menyediakan fasilitas konsultasi yang digunakan untuk melakukan tanya jawab antara sistem dengan pengguna (user) serta juga menyediakan fasilitas untuk melakukan edit knowledge.

\section{Sistem Pakar}

Secara umum, sistem pakar (expert system) adalah sistem yang berusaha mengadopsi pengetahuan manusia ke komputer, agar manusia dapat menyelesaikan masalah seperti yang biasa dilakukan oleh para ahli. Dengan sistem pakar ini, seorang dapat menyelesaikan masalah yang cukup rumit yang sebenarnya hanya dapat diselesaikan dengan bantuan para ahli [8]. Sistem pakar dapat melakukan pengambilan kesimpulan dalam waktu yang konsisten, bahkan dalam beberapa kasus dapat menghasilkan kesimpulan lebih cepat daripada pakar [9]

Ada dua bagian penting dari sistem pakar, yaitu lingkungan pengembangan (development enviroment) dan lingkungan konsultasi (consultation environment). Lingkungan pengembangan digunakan oleh pembuat sistem pakar untuk membangun komponenkomponennya dan memperkenalkan pengetahuan ke dalam knowledge base (basis pengetahuan). [10]

Sistem pakar [11] merupakan sistem yang mengadopsi kemampuan para pakar, sehingga sistem dapat memecahkan permasalahan pada domain tertentu seperti yang biasanya dilakukan oleh para pakar. Sistem pakar memiliki beberapa komponen utama yang terdiri dari:

a. Basis Pengetahuan (Knowledge Base)

Basis pengetahuan berisi pengetahuan-pengetahuan dalam penyelesaian masalah. Ada dua bentuk pendekatan basis pengetahuan yang sangat umum digunakan, yaitu :

1) Penalaran berbasis aturan (Rule-Based Reasoning) 
Pada penalaran berbasis aturan, pengetahuan direpresentasikan dengan menggunakan aturan berbentuk : IF - THEN. Bentuk ini digunakan apabila memiliki sejumlah pengetahuan pakar pada suatu permasalahan tertentu, dan si pakar dapat menyelesaikan masalah tersebut secara berurutan.

2) Penalaran berbasis kasus (Case-Based Reasoning)

Pada penalaran berbasis kasus, basis pengetahuan akan berisi solusi-solusi yang telah dicapai sebelumnya, kemudian akan diturunkan suatu solusi untuk keadaan yang terjadi sekarang (fakta yang ada).

b. Motor Inferensi (Inference Engine)

Motor inferensi (inference engine) berisi metodologi yang digunakan untuk melakukan penalaran terhadap informasi-informasi dalam basis pengetahuan serta digunakan untuk memformulasikan konklusi. Motor inferensi merupakan bagian yang mengandung mekanisme fungsi berpikir dan pola-pola penalaran sistem yang digunakan oleh seorang pakar.

Ada dua cara yang dapat dikerjakan dalam melakukan inferensi, yaitu:

1) Forward Chaining (Alur Maju)

Forward Chaining merupakan strategi yang digunakan dalam sistem pakar untuk mendapatkan kesimpulan/keputusan yang dimulai dengan menelusuri fakta-fakta dan tempat. Forward chaining adalah pencocokan fakta atau pernyataan dimulai dari bagian sebelah kiri (IF dulu). Dengan kata lain, penalaran dimulai dari fakta terlebih dahulu untuk menguji kebenaran hipotesis. Berikut contoh inferensi dengan menggunakan metode alur maju, yaitu:

JIKA demam tinggi dan bintik-bintik merah

MAKA penderita terkena penyakit demam berdarah

2) Backward Chaining (Alur Mundur)

Backward chaining adalah pencocokan fakta atau pernyataan dimulai dari bagian sebelah kanan (THEN dulu). Dengan kata lain, penalaran dimulai dari hipotesis terlebih dahulu, dan untuk menguji kebenaran hipotesis tersebut harus dicari faktafakta yang ada dalam basis pengetahuan.

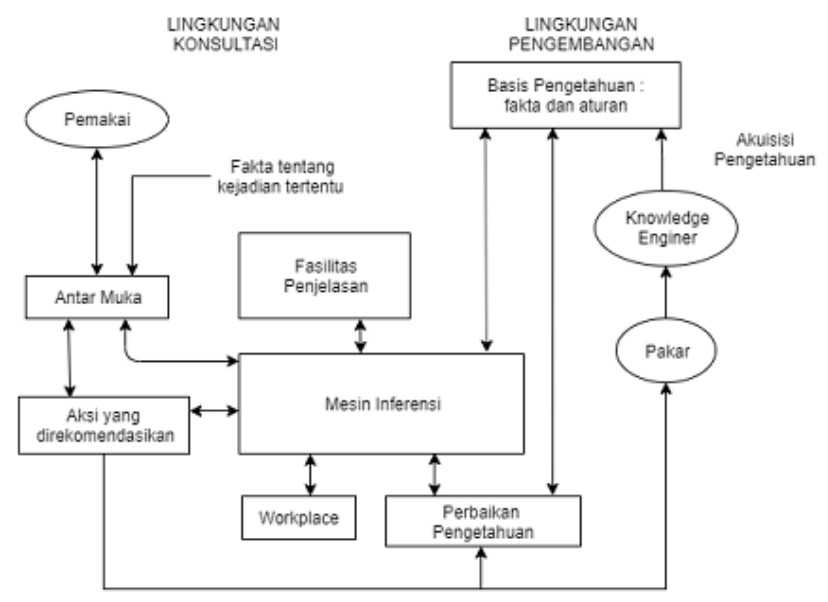

\section{Diabetes Mellitus}

Gambar 1. Struktur Sistem Pakar

Diabetes adalah penyakit menahun (kronis) berupa gangguan metabolic yang ditandai dengan kadar gula darah yang melebihi batas normal. Penyebab kenaikan kadar gula darah tersebut menjadi landasan pengelompokan jenis diabetes mellitus [12][13]

Penyakit Diabetes Melitus terbagi beberapa macam [12], antara lain:

1. Diabetes Tipe 1

Diabetes melitus tipe 1 adalah diabetes yang disebabkan kenaikan kadar gula darah karena kerusakan sel beta pankreas sehingga produksi insulin tidak ada sama sekali. Insulin adalah 
hormone yang dihasilkan oleh pankreas untuk mencerna gula dalam darah. Penderita diabetes tipe ini membutuhkan asupan insulin dari luar tubuhnya

2. Diabetes Tipe 2

Diabetes melitus tipe 2 adalah diabetes yang disebabkan kenaikan gula darah karena penurunan sekresi insulin yang rendah oleh kelenjar pankreas.

3. Diabetes Tipe Gestasional

Diabetes tipe ini ditandai dengan kenaikan gula darah pada selama masa kehamilan. Gangguan ini biasanya terjadi pada minggu ke-24 kehamilan dan kadar gula darah akan kembali normal setelah persalinan

\section{METODE}

Untuk merancang dan membangun system pakar yang dapat membantu pengguna melakukan konsultasi dengan menginputkan gejala-gejala yang dialami sehingga dapat memberikan rekomendasi berupa informasi dan solusi terhadap penyakit tersebut, maka metode penelitian yang dilakukan adalah:

a. Metode wawancara

Metode wawancara secara langsung dalam proses pengumpulan data dilakukan untuk memperoleh informasi (data gejala dan data penyakit) yang efektif dari narasumber atau pakar yang ahli dibidang penyakit diabetes mellitus.

b. Metode studi literatur

Metode ini dengan mengumpulkan referensi dari buku-buku ilmiah, jurnal-jurnal dan sumber-sumber lainnya yang dapat dijadikan sebagai landasan teori dalam penelitian ini.

c. Metode observasi

Metode ini dilakukan dengan melakukan pengamatan secara langsung terhadap obyek penelitian sehingga diketahui adanya keluhan sulitnya melakukan konsultasi melalui sistem yang dibuat

\section{HASIL DAN PEMBAHASAN}

Dalam proses rancang bangun expert system diagnose penyakit diabetes mellitus menggunakan metode forward chaining, maka dilakukan beberapa tahapan, yaitu :

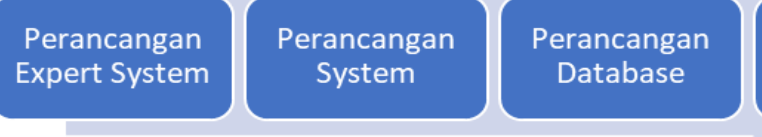

Perancangan

User Interface

Gambar 2. Tahapan Rancang Bangun Expert System Diagnosa Penyakit Diabetes Mellitus menggunakan Metode Forward Chaining

\section{Arsitektur Expert System}

Didalam expert system terdiri dari 3 komponen, yaitu basis pengetahuan (knowledge base), mesin inferensi (inference engine) dan antarmuka (user interface). Dalam penelitian ini mesin inferensi yang digunakan adalah forward chaining, dengan bentuk arsitektur system pakar adalah sebagai berikut :

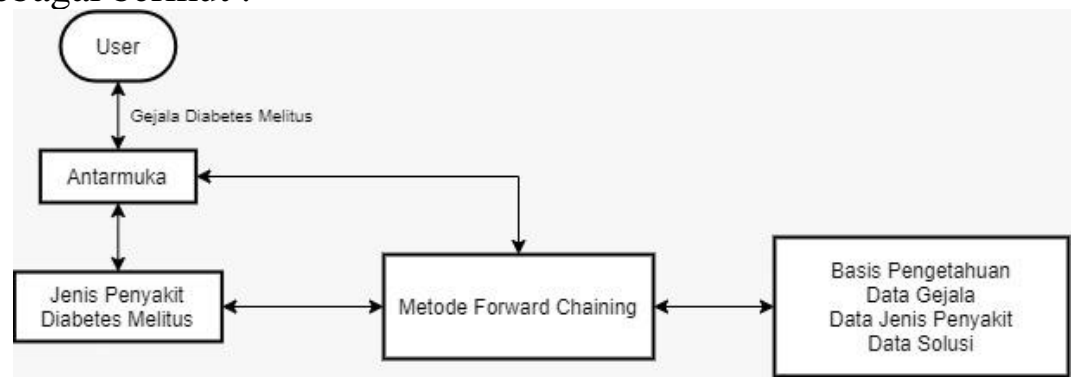

Gambar 3. Arsitektur Sistem Pakar Diabetes Mellitus menggunakan Forward Chaining 


\section{Perancangan Basis Pengetahuan/ Expert System}

Basis pengetahuan berisi pengetahuan-pengetahuan yang diperlukan untuk memahami, memformulasikan dan menyelesaikan masalah. Adapun basis pengetahuan yang dibuat dalam expert system ini adalah sebagai berikut :

\section{a. Data Gejala}

Didalam expert system diagnose diabetes melitus, ditentukan beberapa gejala dari penyakit diabetes melitus. Adapun data gejala diabetes melitus adalah sebagai berikut:

Tabel 1. Nama Gejala Penyakit

\begin{tabular}{llll}
$\begin{array}{l}\text { ID } \\
\text { Gejala }\end{array}$ & Nama Gejala & $\begin{array}{l}\text { ID } \\
\text { Gejala }\end{array}$ & Nama Gejala \\
\hline G-01 & Berat badan turun drastic & G-13 & $\begin{array}{l}\text { Turun berat badan secara tiba-tiba tanpa } \\
\text { alasan jelas }\end{array}$ \\
G-02 & Banyak kencing (polipuria) & G-14 & Gatal disekitar kemaluan \\
G-03 & Banyak makan (polifagia) & G-15 & Tubuh terasa cepat lebih lemah \\
G-04 & Semutan (rasa kesemutan) & G-16 & Kelainan pada kulit menjadi kering \\
G-05 & Sering terjadi kram pada otot & G-17 & Gemetar karena kelebihan lapar \\
G-06 & Banyak minum (polidipsa) & G-18 & Banyak keringat terutama keringat dingin \\
G-07 & Rasa tebal pada ujung kaki & G-19 & Hilang kesadaran \\
G-08 & Sering munckincul bisul ditubuh & G-20 & Suka gelisah \\
G-09 & Luka yang sukar sembuh & G-21 & Sering pingsan \\
G-10 & Mudah terkena infeksi & G-22 & Detakan jantung tidak normal \\
G-11 & Cepat lapar & G-23 & Sering pusing \\
G-12 & Keputihan karena kelainan pada & & \\
\hline
\end{tabular}

b. Data Penyakit

Didalam expert system diagnose diabetes melitus, ditentukan beberapa jenis penyakit dari penyakit diabetes melitus. Adapun data penyakit diabetes melitus adalah sebagai berikut:

Tabel 2. Nama Penyakit

c. Data Solusi

Nama Penyakit

\begin{tabular}{ll} 
ID Penyakit & Nama Penyaki \\
\hline P-01 & Diabetes Tipe 1
\end{tabular}

P-02 Diabetes Tipe 2

P-03 Diabetes Tipe 3 (diabetes

gestasional)

Didalam expert system diagnose diabetes melitus, ditentukan beberapa solusi dari jenis penyakit diabetes melitus. Adapun data solusi dari penyakit diabetes melitus adalah sebagai berikut:

Tabel 3. Nama Solusi

\begin{tabular}{|c|c|}
\hline $\begin{array}{l}\text { ID } \\
\text { Solusi }\end{array}$ & Nama Solusi \\
\hline S-01 & $\begin{array}{l}\text { a. Hormon tertentu untuk mengontrol glukosa darah, dengan cara disuntikkan pada } \\
\text { lapisan dibawah kulit sekitar 3-4 kali sehari sesuai dosis yang dianjurkan dokter } \\
\text { b. Pola makan sehat dan olahraga teratur untuk membantu mengontrol tingkat } \\
\text { glukosa darah } \\
\text { c. Merawat kaki dan memeriksakan mata secara berkala untuk mencegah komplikasi } \\
\text { lebih lanjut }\end{array}$ \\
\hline S-02 & $\begin{array}{l}\text { a. Mempertahankan berat badan ideal dengan mengkonsumsi makanan rendah lemak } \\
\text { b. Mengkonsumsi makanan tinggi serat, seperti buah dan sayuran } \\
\text { c. Mengurangi konsumsi makanan dan minuman manis } \\
\text { d. Berolahraga secara rutin dan banyak melakukan aktivitas fisik } \\
\text { e. Mengurangi waktu duduk dan diam terlalu lama, seperti Ketika menonton televisi } \\
\text { f. Menghindari atau berhenti merokok }\end{array}$ \\
\hline S-03 & $\begin{array}{l}\text { a. Pemeriksaan kadar gula darah secara rutin } \\
\text { b. Diet sehat }\end{array}$ \\
\hline
\end{tabular}




\section{ID}

Solusi Nama Solusi

c. Melakukan olahraga

d. Meminum obat-obatan yang dapat menormalkan kadar gula darah

\section{d. Basis Aturan}

Berdasarkan dari data gejala, data jenis penyakit dan juga data solusi, maka pada rancang model untuk expert system diagnose penyakit diabetes mellitus, dibuat basis aturan untuk menentukan solusi dari diagnose penyakit diabetes mellitus. Adapun basis aturan (rule base) dari diagnose expert system adalah sebagai berikut:

Tabel 4. Rule Base Diagnosa Diabetes Mellitus

\begin{tabular}{|c|c|c|c|}
\hline Data Gejala & P1 & $\mathbf{P 2}$ & P3 \\
\hline Berat badan turun drastic - (G-01) & $\mathrm{V}$ & & \\
\hline Sering muncul bisul ditubuh $-(\mathrm{G}-08)$ & & $\mathrm{V}$ & \\
\hline Keputihan karena kelainan pada ginjal - (G12) & & $\mathrm{V}$ & \\
\hline Gemetar karena kelebihan lapar - (G-17) & & $\mathrm{V}$ & \\
\hline Banyak keringat terutama keringat dingin $-(\mathrm{G}-18)$ & & & $\mathrm{V}$ \\
\hline Banyak kencing (polipuria) $-(\mathrm{G}-02)$ & $\mathrm{V}$ & & \\
\hline Luka yang sukar sembuh $-(\mathrm{G}-09)$ & & $\mathrm{V}$ & \\
\hline Banyak makan (polifagia) - (G-03) & $\mathrm{V}$ & & \\
\hline Cepat lapar - (G11) & & $\mathrm{V}$ & \\
\hline Suka gelisah $-(\mathrm{G} 20)$ & & & $\mathrm{V}$ \\
\hline Semutan (rasa kesemutan) - (G04) & $\mathrm{V}$ & & \\
\hline Detakan jantung tidak normal - (G22) & & & $\mathrm{V}$ \\
\hline Mudah terkena infeksi - (G-10) & & $\mathrm{V}$ & \\
\hline Tubuh terasa cepat lebih lemah $-(\mathrm{G} 15)$ & & $\mathrm{V}$ & \\
\hline Sering pusing $-(\mathrm{G} 23)$ & & & $\mathrm{V}$ \\
\hline Sering terjadi kram pada otot $-(\mathrm{G} 05)$ & $\mathrm{V}$ & & \\
\hline Sering pingsan $-(\mathrm{G}-21)$ & & & $\mathrm{V}$ \\
\hline Gatal disekitar kemaluan - (G14) & & $\mathrm{V}$ & \\
\hline Hilang kesadaran $-($ G19) & & & $\mathrm{V}$ \\
\hline Banyak minum (polidipsa) - (G06) & $\mathrm{V}$ & & \\
\hline Turun berat badan secara tiba-tiba tanpa alas an jelas - (G13) & & $\mathrm{V}$ & \\
\hline Kelainan pada kulit menjadi kering - (G16) & & $\mathrm{V}$ & \\
\hline Rasa tebal pada ujung kaki tangan/kaki - (G07) & $\mathrm{V}$ & & \\
\hline SOLUSI & S-01 & S-02 & S-03 \\
\hline
\end{tabular}

Rule base expert system diagnosa penyakit diabete mellitus adalaha sebagai berikut :

Rule 1

IF Berat badan turun drastic

AND Banyak kencing (polipuria) AND Banyak makan (polifagia)

AND Semutan (rasa kesemutan) AND Sering terjadi kram pada otot

AND Banyak minum (polidipsa) AND Rasa tebal pada ujung kaki tangan/kaki

THEN P-01 (Diabetes Tipe 1)

\section{Rule 2}

IF P-01 THEN S-01

\section{Rule 3}

IF Sering muncul bisul ditubuh AND Luka yang sukar sembuh AND Mudah terkena infeksi AND Cepat lapar

AND Keputihan karena kelainan pada ginjal AND Turun berat badan secara tiba-tiba tanpa alas an jelas

AND Gatal disekitar kemaluan AND Tubuh terasa cepat lebih lemah

AND Kelainan pada kulit menjadi kering AND Gemetar karena kelebihan lapar 


\section{THEN P-02 (Diabetes Tipe 2)}

\section{Rule 4}

IF P-02 THEN S-02

\section{Rule 5}

IF Banyak keringat terutama keringat dingin AND Hilang kesadaran

AND Suka gelisah AND Sering pingsan

AND Detakan jantung tidak normal AND Sering pusing

THEN P-03(Diabetes Tipe 3/ Diabetes Gestasanol)

\section{Rule 6}

IF P-03 THEN S-03

Berikut rancangan rule base diagnose penyakit diabetes mellitus :

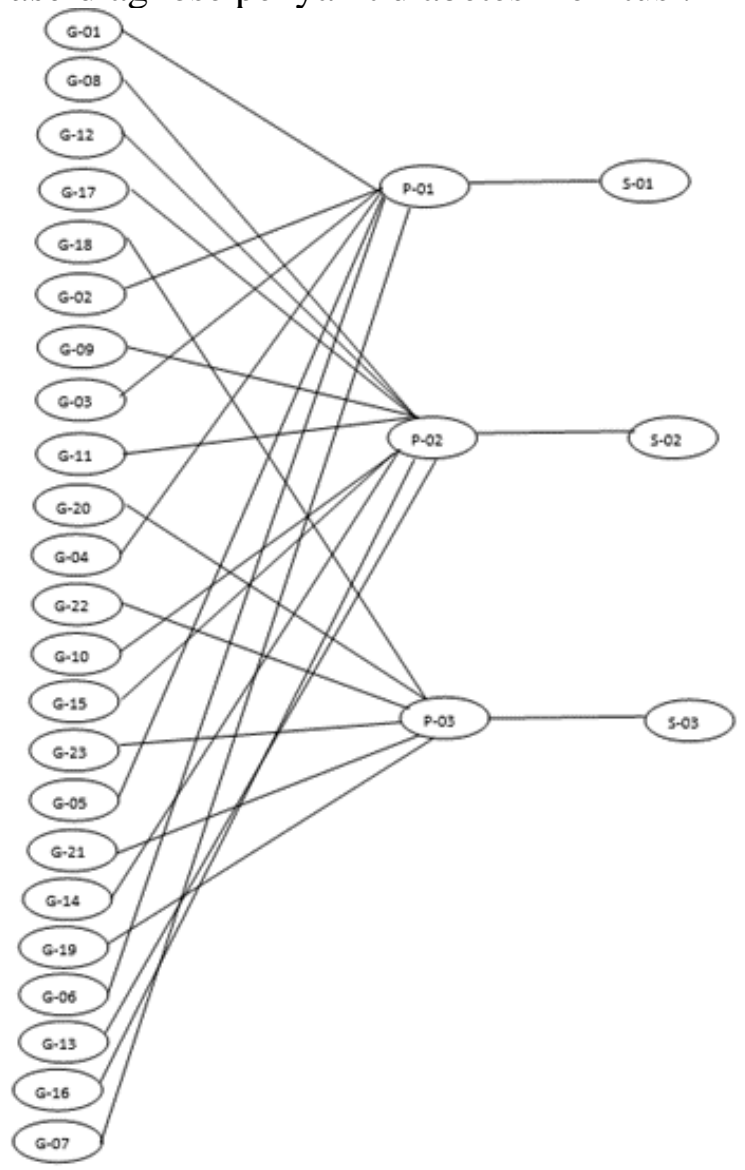

\section{Perancangan Sistem}

Gambar 4. Rule Base Diagnosa Diabetes Mellitus

Dalam membuat suatu aplikasi expert system diagnose diabetes mellitus menggunakan metode forward chaining, maka setelah merancang basis pengetahuan langkah berikutnya adalah merancang system. Adapun rancangan system itu seperti dibawah ini:

\section{a. Flowchart System}

Flowchart ini akan digunakan untuk mendeskripsikan mekanisme kerja aplikasi expert system diagnose diabetes mellitus menggunakan metode forward chaining. Flowchart systemnya dapat dilihat pada gambar dibawah ini: 


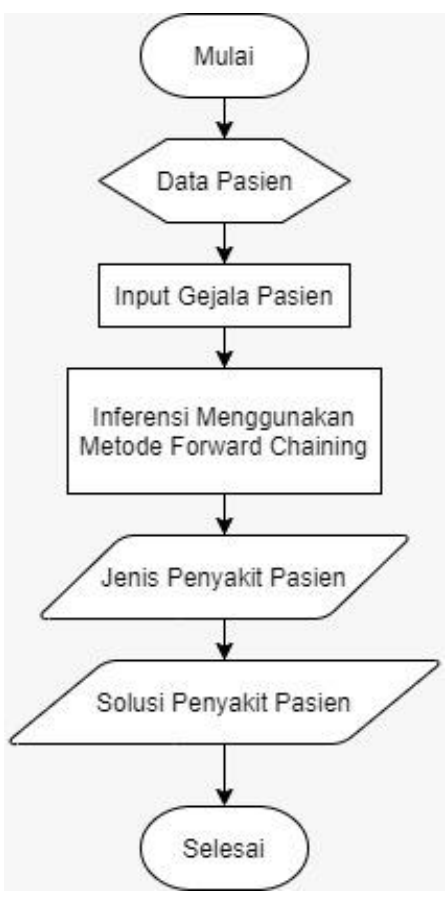

\section{b. Use Case Diagram}

Gambar 5. Flowchart Expert System Diagnosa Diabetes Mellitus

Use Case Diagram ini menggambarkan proses apa saja yang akan berjalan pada sistem pakar.

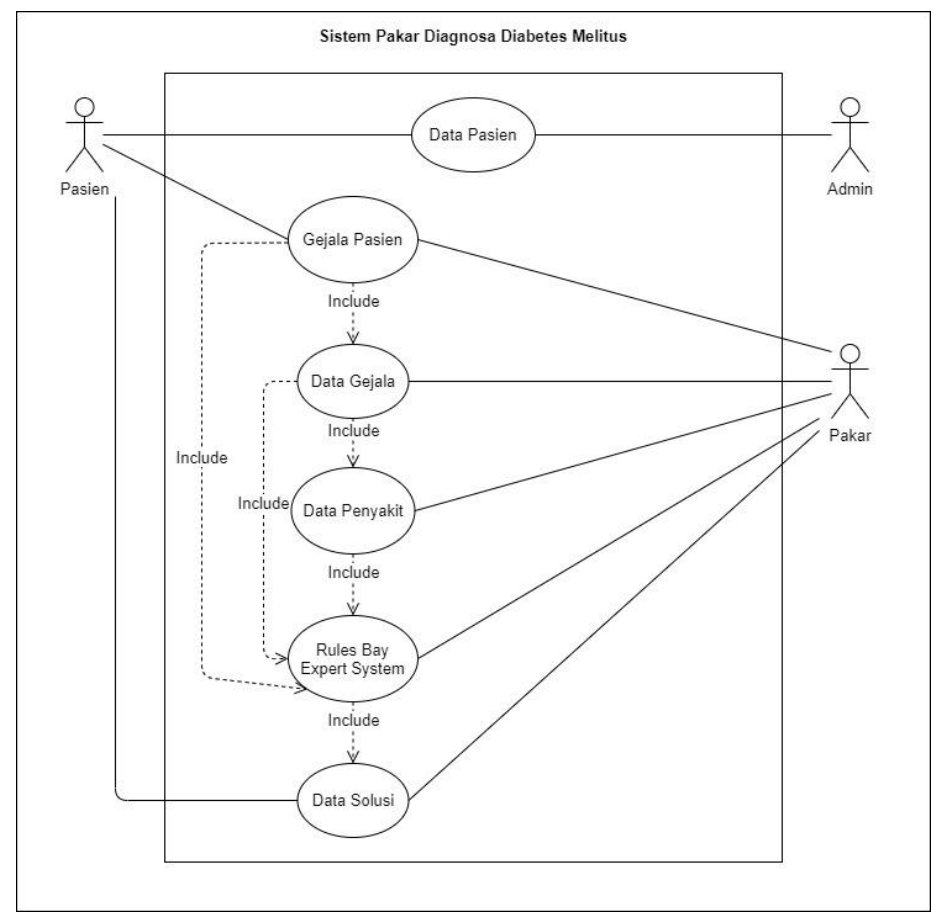

Gambar 6. Use Case Diagram Expert System Diagnosa Diabetes Mellitus

\section{Perancangan Database}

Dalam merancang expert system diagnose diabetes mellitus menggunakan forward chaining, selain merancang arsitektur expert system, basis aturan yang digunakan, merancang sistem yang akan dibuat maka juga perlu dilakukan perancangan basis data. Adapun perancangan basis data adalah sebagai berikut:

\section{a. Perancangan Entity Relationship Diagram (ERD)}

Pada tahap ini menentukan kardinalitas pada setiap entitas yang digunakan, sehingga nilai kardinalitas dapat ditunjukkan seperti dibawah ini: 

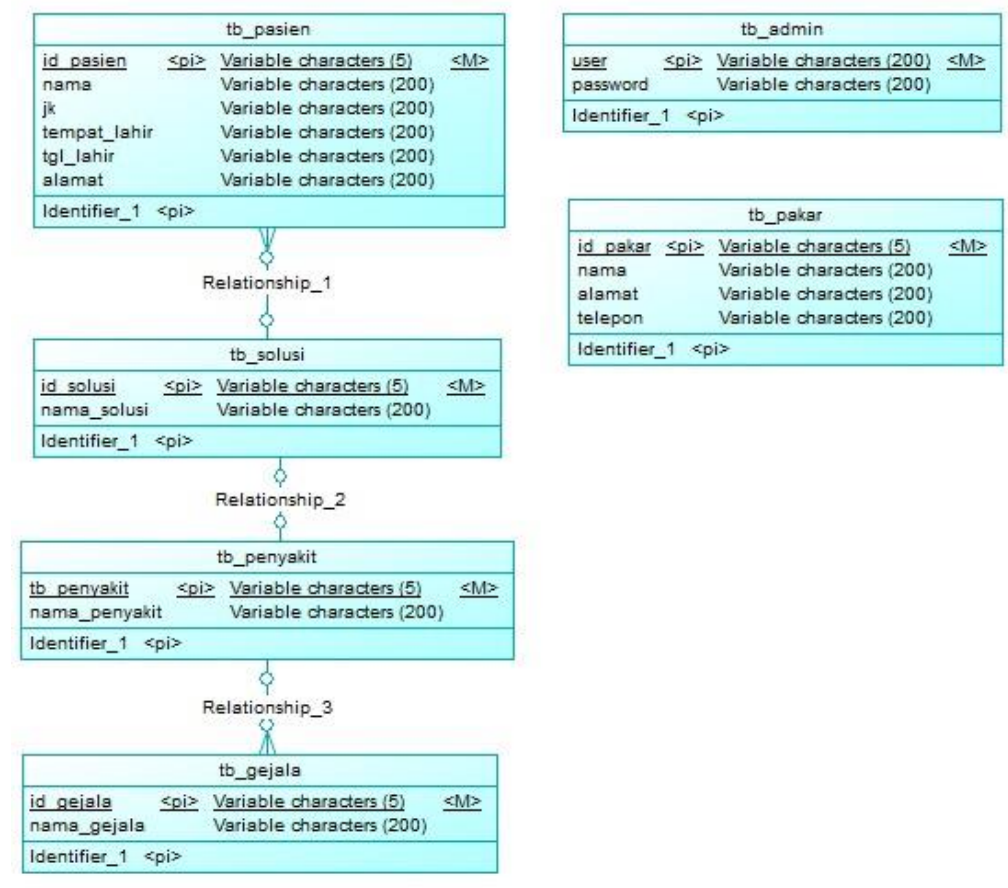

Gambar 7. CDM Expert System Diagnosa Database Mellitus
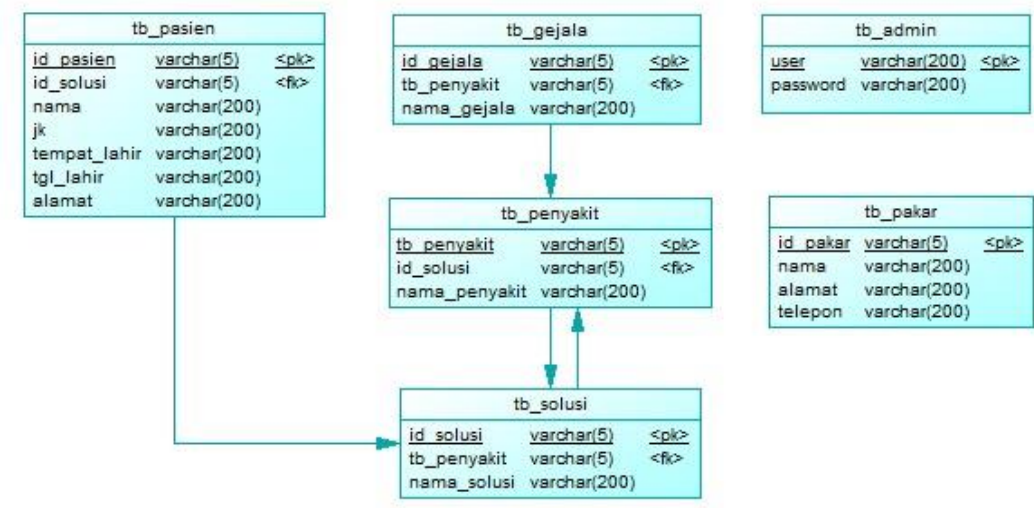

Gambar 8. PDM Expert System Diagnosa Database Mellitus

\section{b. Struktur Basis Data}

Struktur database yang digunakan untuk expert system diagnose diabetes mellitus menggunakan forward chaining adalah sebagai berikut:

Tabel 5. Tabel Gejala

\begin{tabular}{|c|c|c|c|}
\hline No & Nama Field & Type Data & Keterangan \\
\hline 1. & Id_Gejala & Varchar & Id Gejala (PK) \\
\hline 2. & Id_Penyakit & Varchar & Id Penyakit (FK) \\
\hline 3. & $\mathrm{Nm} \_$gejala & Varchar & Nama Gejala \\
\hline & \multicolumn{3}{|c|}{ Tabel 6. Tabel Penyakit } \\
\hline No & Nama Field & Type Data & Keterangan \\
\hline 1. & Id_Penyakit & Varchar & Id Penyakit (PK) \\
\hline 2. & Nm_Penyakit & Varchar & Nama Penyakit \\
\hline & \multicolumn{3}{|c|}{ Tabel 7. Tabel Solusi } \\
\hline No & Nama Field & Type Data & Keterangan \\
\hline 1. & Id_Solusi & Varchar & Id Solusi (PK) \\
\hline 2. & Id_Penyakit & Varchar & Id Penyakit (FK) \\
\hline 3. & Nm_Solusi & Varchar & Nama Solusi \\
\hline & \multicolumn{3}{|c|}{ Tabel 8. Tabel Pasien } \\
\hline No & Nama Field & Type Data & Keterangan \\
\hline 1. & Id_Pasien & Varchar & Id Pasien (PK) \\
\hline 2. & Id_Solusi & Varchar & Id Solusi (FK) \\
\hline
\end{tabular}




\begin{tabular}{clcl}
\hline No & Nama Field & Type Data & Keterangan \\
\hline 3. & Nama & Varchar & Nama Pasien \\
4. & JK & Varchar & Jenis Kelamin \\
5. & Tempat_Lahir & Varchar & Tempat Lahir \\
6. & Tgl_Lahir & Varchar & Tanggal Lahir \\
7. & Alamat & Varchar & Alamat \\
\hline \multicolumn{4}{c}{ Tabel 9. Tabel Pakar } \\
\hline No & Nama Field & Type Data & Keterangan \\
\hline 1. & Id_Pakar & Varchar & Id Pakar (PK) \\
2. & Nama & Varchar & Nama Pakar \\
3. & Alamat & Varchar & Alamat Pakar \\
4. & Telp & Varchar & Telp. Pakar \\
\hline \multicolumn{4}{c}{ Tabel 10. Tabel Admin } \\
\hline No & Nama Field & Type Data & Keterangan \\
\hline 1. & User & Varchar & User \\
2. & Pwd & Varchar & Pasword \\
\hline
\end{tabular}

\section{Perancangan User Interface}

Dalam merancang expert system diagnose diabetes mellitus menggunakan forward chaining, juga melakukan perancangan user interface sebelum diimplementasikan kedalam sebuah aplikasi. Adapun perancangan user interface adalah sebagai berikut:

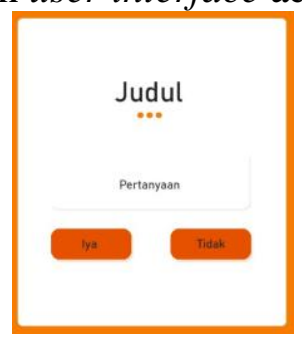

Gambar 9. Rancangan User Interface "Daftar Pertanyaan"

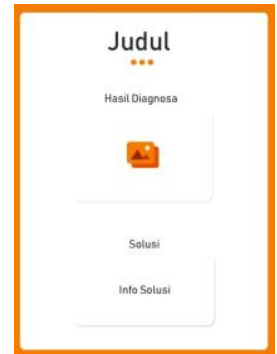

Gambar 10. Rancangan User Interface "Hasil diagnosa"

\section{SIMPULAN DAN SARAN}

Dari hasil pengamatan dan uji coba yang telah dilakukan dalam penelitian ini, dapat diambil beberapa kesimpulan sebagai berikut:

1. Rancangan basis pengetahuan, rule base expert system, rancangan system, rancangan database dan juga rancangan UI dapat digunakan untuk membangun suatu aplikasi expert system untuk diagnose penyakit Diabetes Mellitus dengan menggunakan beberapa gejala yang dialami oleh pasien.

2. Dalam rancangan expert system ini dapat mendiagnosa diabetes yang meliputi diabetes tipe 1, diabetes tipe 2, dan diabetes tipe 3 dan juga memberikan solusi terhadap gejala yang dialami oleh pasien.

Berikut beberapa saran yang dapat dilakukan untuk tahapan penelitian berikutnya :

1. Metode inferensi yang berbeda tidak hanya menggunakan metode forward chaining.

2. Parameter yang digunakan untuk menggunakan diagnose penyakit diabetes mellitus dapat menggunakan parameter yang lain 


\section{DAFTAR PUSTAKA}

[1] Widodo, B. dan Suhartono, D., 2014. Artificial Intelligence Konsep Dan Penerapannya. 1 ed. Yogyakarta: C.V Andi Offset.

[2] Hadi, M., Aini, R.F., dan M.Misdram, (2016). Perancangan Sistem Pakar Diagnosa Penyakit Ayam Dengan Metode Forward Chaining, 2 (1).

[3] Setiabudi, W.U., Sugiharti,E., \& Arini,F,Y. (2017). Expert System Diagnosis Dental Disease Using Certainty Factor Method. Scinetific Journal of Informatics. 43-50

[4] Halim, S. dan Hansun, S. (2018). Penerapan Metode Certainty Factor dalam Sistem Pakar Pendeteksi Resiko Osteoporosis dan Osteoarthritis, Journal Ultimate Computation, 7(2), 59-69.

[5] Rofiqoh, Siti., Kurniadi, Dedi., \& Riansyah, Andi. (2020). Sistem Pakar Menggunakan Metode Forward Chaining untuk Diagnosa Penyakit Tanaman Karet. Sultan Agung Fundamental Research Journal. Vol 1 No 1, Januari 2020

[6] Pasali, Christian R., Poekoel,Vecky C., \& Najoan,Xaverius. (2016). Sistem Pakar Diagnosa Penyakit Menggunakan Metode Forward Chaining Berbasis Mobile. EJournal Teknik Informatika Vol 7 No 1, Juli 2016.

[7] Nurliana P, Rizka. \& Goeirmanto, Leonard. (2020). Aplikasi Sistem Pakar untuk Diagnosa Penyakit Diabates Mellitus dengan Algoritma Certainty Factor Berbasis Web. Jurnal Aplikasi dan Inovasi Ipteks SOLIDITAS. ISSN Online: 2620-5068. Vol 3 No 2, Oktober Tahun 2020. Hal 106-112

[8] Meyliana,A., Kusrini \& Taufiq Luthfi,Emha. (2016). Sistem Pakar Pada Konsultasi Jenis Senam dengan Metode Forward Chaining. Jurnal INFORMA Politeknik Indonusa Surakarta. ISSN: 2442-7942 Vol 1Nomor 3 Tahun 2016, 10-15

[9] Nugroho, F.A., (2018). Perancangan Sistem Pakar Diagnosa Penyakit Jantung Dengan Metode Forward Chaining, 3 (2), 75-79.

[10] Kristiana,Titin. (2018). Sistem Pakar untuk Mendiagnosa Penyakit Saluran Pencernaan dengan Metode Forward Chaining. ISSN 2656-139X. Informatik Jurnal Ilmu Komputer, Vol 14 No 2 (2018)

[11] Sugiharni, Gusti Ayu Dessy \& Divayana, Dewa Gede Hendra (2017). Pemanfaatan Metode Forward Chaining dalam Pengembangan Sistem Pakar Pendiagnosa Kerusakan Televisi Berwarna. Jurnal Nasional Pendidikan Teknik Informatika (JANAPATI). eISSN: 2548-4265 Vol 6 Nomer 1 Maret 2017.

[12] Kementerian Kesehatan Republik Indonesia. (2020). InfoDATIN. Pusat Data dan Informasi Kementerian Kesehatan RI. ISSN 2442-7659

[13]Hestiana, D. W. (2017) Faktor-Faktor yang Berhubungan dengan Kepatuhan dalam Pengelolaan Diet pada Pasien Rawat Jalan Diabetes Mellitus Tipe 2 di Kota Semarang', J. Health Education, 2(2), 138-145. 